\title{
Két középkori kályhacsempe fekete mázának meglepő anyagvizsgálati eredménye, és ennek magyarázata
}

\author{
VÉNINGER PÉTER
}

H-1151, Budapest, Töltés utca 17., keramikus@gmail.com

Véninger, P.: Material testing report of the black glaze of two tile stoves from the Middle Age

Abstract: During the examination of the two black glazed tile stoves from Nyírbátor, we couldn't decide if the black colour was the result of a technological mistake or it was coloured on purpose. Because of that, we have come to a decision to examine the tiles with the help of electron microscopy. Our hypothesis was that in the case of conscious color management we will find ordinary materials such as manganese ( $\mathrm{Mn}$ ), cobalt (Co), iron (Fe) in the glaze. On the other hand, if the black colour is the result of a mistake, it could be the consequence of an undue burning atmosphere. In this case, the outcome presumably would be a green or yellow glaze. The examination has come to a different conclusion.

Keywords: tile stove, black glaze, iron silicate, Nyírbátor

\section{Bevezetés}

Szeretném bemutatni egy korabeli kályhakészítő mester igen egyedi és furfangos megoldását, aminek segítségével fekete mázas kályhacsempét készített.

Egy-egy régészeti szempontból fontos kérdés megválaszolására már nem számít kuriózumnak a régészeti leletek anyagvizsgálata. Az alábbiakban szeretnék bemutatni egy példát, ahol szemrevételezés után elvégzett, szinte rutinszerűnek induló vizsgálat egészen meglepő eredményt hozott.

Duma György által gyakran alkalmazott módszer, hogy az anyagvizsgálatok eredményeit összekapcsolja kísérleti régészettel. A technológia-rekonstrukció kísérlet segített értelmezni az anyagvizsgálat során kapott szokatlan adatokat.

A nyírbátori várból Virágos Gábor ásatásán előkerült kályhacsempéket Eleki Nándor dolgozta fel diplomamunkájában. A szemrevételezés során két kályhacsempe mázának fekete színe felkeltette az érdeklődését, és 2011 tavaszán azzal a kérdéssel keresett meg, hogy vizsgáljuk meg, hogy a fekete színű máz tudatos, vagy pedig egy technológiai hiba (véletlen) eredménye.
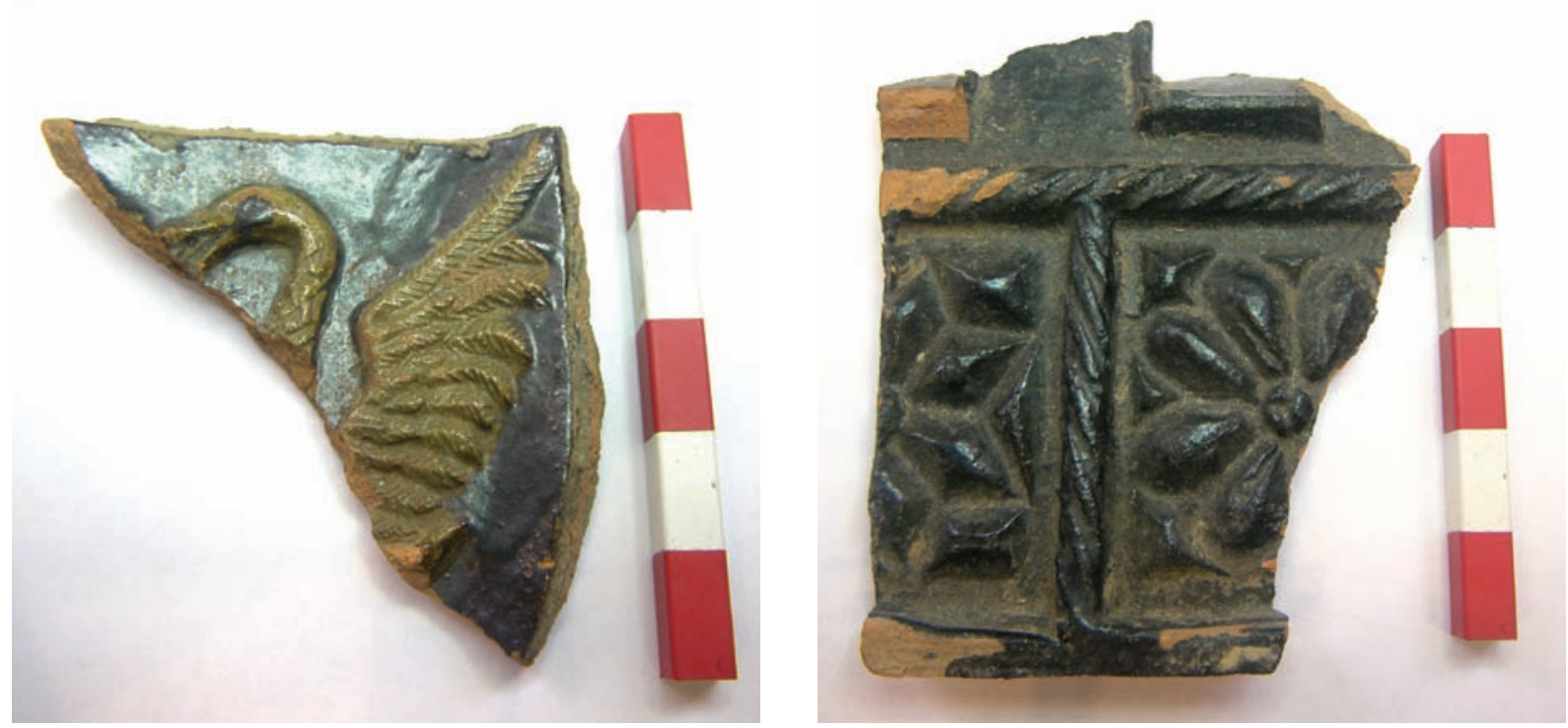

1-2. kép: Nyírbátori fekete mázas kályhacsempék

ISSN 2064-1966 (Print); ISSN 2631-0376 (Online) 
A két kályhacsempe a 15. század végére keltezhető', és az eddigi ismereteink alapján a fekete színú mázak Itáliában jelennek meg a 16. században. Amennyiben a kályhacsempéken szándékosan létrehozott fekete mázat találunk, akkor ez jelentős.

A csempék vizsgálata egy egyszerú kérdéssel indult, és szinte rutin vizsgálatnak lehetett tekinteni. Ám igen szokatlan mérési eredményeket kaptunk. Talán ennek fényében érdemes átgondolni néhány rutinszerűen bevett eljárást a kerámiák szemrevételezésével kapcsolatban.

\section{Csempék szemrevételezése}

Alaposabb szemrevételezés során néhány olyan apró részletet lehetett megfigyelni, ami kissé szokatlannak számít.

A madár címeres csempe (1. sz. csempe, később 3. minta) fekete máza bizonyos szögben tartva fémesen csillog. Más szögből nézve fekete. Mivel a madár színe zöld, a háttér fekete, ez elvileg a tudatos fekete szín felé billenti a mérleget. Mivel a fekete színű máz meglehetősen ritka, ezért fontosnak érzem, hogy a kerámiák színezésével kapcsolatos tudnivalókat (amelyek nagy része közismert) röviden összefoglaljam. Ezek megértése után könnyebb megérteni, hogy miért szokatlan ennek a csempének a máza.

A rozettás csempe (2. sz. csempe, később 5. minta) máza nem túl fényes. Ennek oka lehet károsodás (üvegkorrózió) is. Okozhatja az is, ha égetés közben a máz felületére egy kevés hamu ég. Akkor kerül égetés közben hamu a mázra, ha túl nagy a kemencében a huzat.

\section{Kerámiák színezőanyagai}

Kerámiákat kétféle festéktípussal szokás színezni: engóbokkal és mázakkal.

Az engóbokat megfogalmazhatjuk agyag kötőanyagú festékként. A mázakat, pedig üveg kötőanyagúnak. (Természetesen a kemencében a magas hőmérséklet hatására megolvadt máz üveges fázisa válik kötőanyaggá.)

Önként adódik a kérdés, hogy vajon miért használnak kerámiában kétféle festéktípust is?

Ha alaposabban megnézzük, hogy a 15. században (és nagyjából a 19. századig tartó időszakban) milyen színeket lehet előállítani engóbokkal és mázakkal, akkor kiderül, hogy engóbokkal a fehér, sárga, vörös, barna és nagyon ritkán zöldes, esetleg fekete színek állíthatóak elő.

A mázakkal szinte minden szín előállítható ${ }^{2}$, de a piros és vörös színek nem. ${ }^{3}$ (Vigyázni kell a szakirodalomban szereplő leírásokkal, mert az ilyen korban készült edényeknél gyakran tévesen máznak írják le a vörös színű engóbokat! Ennek oka, hogy a vörös engób és a felette levő átlátszó színtelen máz együtt valóban túnhet vörös színű máznak.)

Megállapíthatjuk, hogy egyik festéktípus sem alkalmas önmagában arra, hogy az összes szükséges színt létrehozzunk velük. ${ }^{4}$

Szerencsés módon, az egyik hiányosságát pótolja a másik. Ez a magyarázata annak, hogy igen gyakran engóbot és mázat is használnak a fazekasok egy tárgyon. Ezért színenként, egyesével kell megvizsgálni a díszítést a tárgyak leírásánál. Közismert példák a „,metélt mázas” és „folyatott engóbos” (téves, de gyakori nevén „folyatott mázas") ${ }^{5}$ kerámia néven ismert típusok. Szintén ezt a logikát követik a magyar népi kerámiák készítése. Sőt, az elvileg tisztán csak mázakat használható olasz reneszánsz majolikák között is előfordul, hogy bizonyos színeket engóbokkal hoznak létre mázak helyett. ${ }^{6}$

\section{Az égetés hatása a színre}

Az engóbokon és a mázakon kívül egy másik lehetőség, amikor a kerámiák színét befolyásolni tudjuk, ez pedig maga az égetés. A tüzelés technológiájától függően ugyanazt az agyagot a fazekas vörösre, sárgára, barnára, szürkére vagy feketére tudja égetni. Minden „cserépszín” más és más kémiai és fizikai folyamat eredményeként jön létre. A feketére égetett kerámiák a régészetben és néprajzban közismertek. Az azonban már kevésbé ismert, hogy a kerámiamáz hogyan viselkedik a vörös égetéstől eltérő égetéseknél.

Az is ismert, hogy egy mázat színező anyag más színű lesz oxidáló és redukáló égetésnél.?

A régészeti adatokat Eleki Nándor bocsátotta rendelkezésemre, ezt ezúton is szeretném megköszönni.

2 Jakó 1934. „...vannak színek, mint pl. törökkék, cseresznyepiros, lila stb. színek egyszerü ólmos mázakkal nem állíthatóak elő."

3 A piros mázak Magyarországon csak az 1930-as évek végén terjedtek el.

4 Természetesen ez csak a történeti kerámiaanyagra vonatkozik. Ma már mindenféle színt elő lehet állítani.

5 Ennél a kerámiatípusnál valójában engóbot folyat a fazekas. A folyatott mázas kerámia név sajnos félrevezető.

6 A ,testszínt” engóbbal festették. Mivel az engób égetés után matt, ezért átlátszó színtelen máz (coperta) kell fölé.

7 Pl. a rézzel színezett máz vörös (oxidáló) égetésnél zöld, de szürke (redukáló) égetésnél vörös lesz. 
A mázas kerámiáknál szinte kivétel nélkül csak vörös égetésre való mázakkal találkozunk. Eltérő égetésnél a mázak gyakran különböző hibákat okoznak. ${ }^{8}$

A fekete mázas kályhacsempéknél elvileg tudatos színezés eredményét is láthatjuk. De ugyanígy lehetséges, hogy egy égetés közben elkövetett hiba következményét látjuk.

A középkorban és kora újkorban kerámiamázak színezésére használt anyagok száma nem túl nagy. Sajnos pont emiatt nem tehetjük meg azt, hogy mázat készítünk az első fekete színű anyaggal, amit találunk. A jó színezőanyagnak el kell viselnie közel 1000 fokot anélkül, hogy elbomlana, reagálna a mázzal (ami egyébként igen erős oldószernek tekinthető, hiszen a cserép felső rétegét is oldja). Ráadásul a színét is meg kell tartania.

Közismert az a néhány színezőanyag, ami a régészeti leletként előkerülő kerámiák mázaiban gyakran előfordul. Ezeknél könnyen megfigyelhető, hogy nagyjából egy anyag egyféle színért felelős. És fordítva: egy színt valószínűleg egy színezőanyag okoz. Ezért a mázas kerámiák leírásánál rendszerint azt szokás követni, hogy anyagvizsgálat nélkül, csupán szemrevételezésre alapozva nevezzük meg a mázakat színező anyagokat. ${ }^{10}$

Ezt a logikát követve meg kéne nevezni azt az egy olyan anyagot, ami feketére színez. De ilyen anyagot nem ismertek ekkor. ${ }^{11}$

A következőkben ismertetem az elvileg lehetséges megoldásokat.

\section{Mázakban fekete színt létrehozó anyagok ${ }^{12}$}

Sötét színú lesz egy átlátszó máz, ha viszonylag sok mangán vagy sok kobalt van a mázban. Vörös cserépen közvetlenül az ilyen átlátszó, sötét színú máz feketének hat. ${ }^{13}$ Ez azonban viszonylag hamar megkülönböztethető a valóban fekete mázaktól. Ha a kályhacsempéken levő fekete máz tudatos színezés eredménye, akkor csak néhány lehetőséggel számolhatunk. Az első az, ami szinte az összes eddig ismert fekete kerámiára jellemző.

\section{Fekete máz több sötét szín keverékével}

A fekete mázak a 16. századtól máig leggyakrabban a következő színezőanyagokat tartalmazzák: mangán, kobalt és vas, esetleg még mellette réz ${ }^{14}$ is. A különböző anyagok eltérő mértékben színeznek, így mindegyikből más és más mennyiséget kell a mázba kevernünk, hogy valódi feketét kapjunk. Legkevesebb a kobaltból kell, mert ez nagyon erős színezőanyag. A kobalt kis mennyisége miatt (fél \% alatti) az anyagvizsgálatoknál a kobaltra kiemelten kell figyelni.

Ha kivilágosítanánk a fekete mázakat, akkor gyakran kiderülne, hogy a fekete szín valójában sötétbarna, vagy piszkos kék szín. ${ }^{15} \mathrm{Ha}$ a fekete máz elterjedt lenne, ilyen módon meg lehetne különböztetni egymástól a különböző recepteket használó műhelyeket. De sajnos a fekete máz ritka.

\section{Fekete vas-oxidok}

Wüstit ( $\mathrm{FeO})$ és a magnetit $\left(\mathrm{Fe}_{3} \mathrm{O}_{4}\right)$. A fekete vas-oxidok kerámiában csak redukciós atmoszférában stabilak. Vörös (oxidáló) égetésnél a fekete vas-oxiddal készített máz okkersárga lesz. Kerámiamázak színezésére nem használatosak közvetlenül, de redukáló atmoszféra esetén ezek egyike vagy mindkettő keletkezhet mázban. ${ }^{16}$ Magasabb hőmérsékleten (1000 Co felett) könnyebben marad stabil. Fazekasárun (1000 Cº alatt égetett kerámián) nem valószínú a felbukkanása.

A két fekete vas-oxid ismertetése után fontos, bár látszólag kitérő a vörös vas-oxid szerepe a mázakban:

8 Sárga égetést biztosan, és valószínűleg a barna égetést is jól bírják ezek a mázak. A színük nem változik, de a szürke és fekete égetésnél tönkremennek, és szürkévé válnak.

9 Ezek a közismert mázakat színező ionok a következők: fehér: ón, sárga: antimon, okker színű: vas, barna: mangán, zöld: réz, kék: kobalt. A színező ionok miatt szokás egy-egy színezőanyagra csak az adott fém nevével (pl. mangán) utalni. Néha pedig a felhasznált alapanyag teljes nevét (pl. mangán-oxid) használjuk. Természetesen egy fém, és annak oxidja két különböző anyag. De kerámiában gyakran helyettesítik egymást szövegben. Ezért szokás a konkrét anyag pontos megnevezése helyett röviden csak a ,lényeges részt” említeni. A klasszikus színezőanyagokat és egyéb alapanyagokat hagyományosan oxidnak tekintjük. Ha nem azok, akkor pedig oxidokra szokás ,átszámolni” a receptekben.

10 Ez olcsó és gyors eljárás, de ennek ,,köszönhetően” nem tudjuk, hogy a modernnek tartott króm mikor jelenik meg, mert mindenki réznek gondolja. Ezen kívül azt sem tudjuk, hogy az igen drága ón pótlására mikor és milyen anyagokkal próbálkoztak. A két- vagy több színezőanyagból kevert színek szintén nem ismertek.

11 Modern színezőanyagok között van, ami feketére színez, de ezeket akkor még nem ismerték. Ma csak a porcelánfestészetben használják gyakran, mert nagyon drágák.

12 Azokat kell figyelembe vennünk, amelyek régi kerámiákban előfordulhatnak. Ezért nem tárgyalom a modern mázakban használt anyagokat, mint pl. az irídium, vagy az uránnal redukciós égetéssel előállított fekete.

13 Elég sok példát lehet látni ennek kihasználására Az egyik leginkább jellegzetes a magyar népi kerámia butelláin. A jelenség leírása pl. Jakó 1934. 135.

14 Modern mázakban a rezet helyettesítheti króm. Jakó 1934. 1,5 rész Co, 8 rész Mn, 2 r Cr.

15 Az Örley fekete máz oxidjainak aránya a következő: 1 rész $M n, 2$ rész Co, 8 rész Fe. Ez az arány megbízható.

16 Kozma 1998. 100. 


\section{A vörös vas-oxid}

A három leggyakoribb vas-oxid közül messze a legismertebb oxid a vörös vas-oxid, amely (többek között) a kiégetett kerámiák vörös színéért is felelős. Ez keletkezik vörös égetés közben. A teljesség kedvéért érdemes kitérni erre a színezőanyagra is. (Később kiderül, hogy ez még fontos lehet.) Ez a színezőanyag a középkorban használt ólmos mázban okkersárga színt ad, amit minden régész és fazekas jól ismer. Ennek sajátossága, hogy fatüzelésű kemencében enyhe redukciós hatásra foltokban zöldes színúvé válik. Régészeti leleteken láthatjuk ezt a színt is. A vas-oxid az ólommentes mázat vörösesbarnára színezi. Redukciós hatásra az ólommentes mázban is zöld színű lesz. ${ }^{17}$

\section{Technológiai hibák, melyek feketévé tehetik a mázat}

Amennyiben a fekete kályhacsempék máza valamilyen technológiai hiba miatt ilyen, akkor a következő három lehetőség túnik a legvalószínúbbnek: A máz „megette" az engóbot, a máz füstössé vált, vagy túladagolták a máz színezőanyagát. Ezek részletes leírása a következő:

\section{A máz ",megette" az engóbot}

A hiba természetéből következik, hogy csak engóbos kerámiák hibája lehet. A fazekasok ennek a hibának nagyon kifejező nevet adtak. Az engób felett levő máz oldja az engób felső rétegét (így kapaszkodik hozzá). Ha a máz teljes keresztmetszetében feloldja az engób teljes rétegét, akkor az engób látszólag eltűnik, és az alatta levő cserepet látjuk. Ha a cserép vörös színű, a máz zöld, akkor a két színt együtt feketének látjuk. Ha a kék máz „ette meg" az alatta levő engóbot, akkor is fekete színúnek látjuk. ${ }^{18}$

\section{A máz füstössége ${ }^{19}$}

Szabad szemmel azt látjuk, hogy a máz felülete foltosan szürkévé vált. A fazekasok azt mondják, hogy a máz füstös lett. A kerámia látványa gyakran valóban erre emlékeztet. Ez a felületi szürke színú réteg elfedi az alatta levő máz színét. Ez a hiba inkább szürke színúvé teszi a mázat, mint feketévé, de ennek ellenére nem szabad kizárni ennek a lehetőségét sem teljesen. Jakó Géza szerint az égetés közben a kemencébe jutó kén, szén-monoxid és a vízgőz a mázakat mattá, túszúrásossá és feketévé teszi. ${ }^{20} \mathrm{~A}$ szöveg erősen sürített, s nem tárgyalja külön a különböző hibákat okozó anyagokat. A szén-monoxid jelenléte erősen redukciós égetési atmoszférát feltételez.

Az égetés nem megfelelő atmoszférája gyakran megváltoztatja a mázak színét. Redukciós égetésnél az ólmos mázban levő ólom-szilikát a máz felületén fém ólommá válik ${ }^{21},{ }^{22}, 23$. Ez a fém ólom azonban nem oldódik az ólmos mázban, ezért elektronmikroszkóp alatt kisebb-nagyobb fém ólom gömböket látunk. Ha egy redukció miatt szürke mázat vizsgálunk, akkor az eredeti színért felelős színezőanyagokat találjuk a mázban. Például, ha egy zöld máz vált szürkévé, akkor a színezőanyagok közül csak rezet találunk.

\section{Túladagolt színezöanyag}

Amennyiben a fazekas a megszokottnál jóval több színezőanyagot ad a mázhoz, akkor a máz teljesen másmilyen színủ lesz, mint amilyennek lennie kéne. A végső szín az összetételtől függ. A túl sok réz, mangán, vagy kobalt fémes szürkévé teszi a mázat. ${ }^{24} \mathrm{Nem}$ lesz grafitos a túladagolt ón, antimon, vas és króm.

Első ránézésre ez hasonlít a redukciós atmoszféra okozta hibára, de túladagolt színezőanyag miatt a máz teljes felülete egységesen fémes szürke lesz. Néha kifejezetten a grafithoz hasonlít a máz megjelenése. A fekete kályhacsempe máz fémes csillogása hasonlít kicsit ehhez a hibához. De a túladagolt színezőanyag mindenféle szögből nézve fémes. Ezzel szemben a kályhacsempén a fémes csillogás csak bizonyos szögből látható.

17 Ez utóbbit szeladon máz néven ismerjük.

18 A teljesség kedvéért meg kell jegyezni, hogy léteznek középkori kerámiák, amelyek máza alatt nincs engób, és a máz színe mégis tökéletesen érvényesül. Ennek oka a felhasznált agyag összetételében kereshető. Az ilyen agyagok valószínűleg magas alumínium- és/vagy szilícium-dioxid tartalmúak. Később feledésbe merült az ilyen jó tulajdonságú agyagok használata.

19 Ez a kifejezés a mai napig használatos. Használja például: Kozma 1998. 37.

20 Jakó 1934. 39.

21 Mattyasovszky 1953. 161.: „Az ólommázat nem égethetjük redukáló kemencetérben, mert az ólom redukálódik, a máz „füstössé" válik..."

22 Petrik 1914. 144.: „A leggyakoribb hiba, mi a füstgázoktól származik, hogy az áru füstös lesz. A tökéletlen elégéskor képződő redukáló gázok (szénoxyd) és a füst az ólomoxydos mázakat redukálja, mikor a kivált ólom szürkésfekete szinüvé és fénytelenné teszi a mázat."Az említett szén-oxid alatt szén-monoxid értendő.

23 Hinsenkamp - Falussy - Richter 1961. 463.: „Ólmos mázak redukáló égetés esetén fém ólom kiválása következtében megszürkülnek.” Valamivel lejjebb: „Rendkívül erős redukció következtében a porcelán máza koromlerakódás, esetleg SiC képződésével megfeketedhet."

24 Gebauer 1985. 133. Ebben a könyvben a színező-oxidok túladagolást hasonlóan írja le, de fémes színűnek írja a vas-oxidokat is, amik tapasztalataim szerint fazekasárun (ólmos mázban) nem teszik a mázat egységes fémes szürkévé. Ezért a vas-oxidot kihagytam. 


\section{Középkori kályhacsempék mázainak összetétele}

\begin{tabular}{|l|l|l|l|l|l|l|l|l|l|l|}
\hline $\mathrm{Sz}$ & $\mathrm{SiO}_{2}$ & $\mathrm{Al}_{2} \mathrm{O}_{3}$ & $\mathrm{Fe}_{2} \mathrm{O}_{3}$ & $\mathrm{TiO}_{2}$ & $\mathrm{CaO}$ & $\mathrm{MgO}$ & $\mathrm{K}_{2} \mathrm{O}$ & $\mathrm{Na}_{2} \mathrm{O}$ & $\mathrm{PbO}$ & $\mathrm{CuO}$ \\
\hline 1. & 14,10 & ny. & 1,35 & 0,02 & - & - & - & ny. & 83,70 & - \\
\hline 2. & 14,50 & ny. & 2,60 & 0,01 & - & - & - & - & 82,80 & - \\
\hline 3. & 18,53 & 0,20 & 0,6 & 0,01 & ny. & - & - & - & 76,70 & 3,38 \\
\hline 4. & 18,10 & 0,25 & 1,40 & 0,01 & ny. & - & - & - & 76,20 & 3,25 \\
\hline 5. & 22,50 & $4,10^{*}$ & 7,30 & 0,02 & ny. & - & - & ny. & 65,85 & - \\
\hline 6. & 20,58 & 0,20 & 3,00 & 0,01 & ny. & - & - & - & 72,05 & 3,50 \\
\hline 7. & 21,95 & 0,19 & 0,90 & ny. & ny. & ny. & - & - & 72,30 & 3,38 \\
\hline 8. & 33,50 & 0,10 & 2,80 & ny. & ny. & ny. & ny. & - & 63,00 & - \\
\hline
\end{tabular}

*4,10 $\mathrm{Al}_{2} \mathrm{O}_{3}$ megfelel 10,45 kaolinitnek, ami 4,87 $\mathrm{SiO}_{2} \%$ tartalmaz

Átlagosan igen magas 70-80\% ólomtartalomra számíthatunk. (Ez az magas ólomtartalom az oka annak, hogy a mázak nagyon folyósak voltak a középkorban.)

\section{A vizsgálat}

Az eredeti kérdés, hogy a fekete színú máz tudatos-e, vagy pedig egy technológiai hiba (véletlen) eredménye-e.

Ezt a kérdést a vizsgálat szempontjából úgy pontosíthatjuk, hogy ha a máz színezőanyagai közül csak vasat vagy csak rezet tudunk kimutatni, akkor a máz fekete színe technológiai hiba eredménye. Ha a mázban a vason kívül mangánt, kobaltot és esetleg rezet is, akkor pedig tudatos színezés. Ennek eldöntésére egy múgyantába ágyazott, egyik oldalán megcsiszolt, polírozott mintát elvittünk a Bűnügyi Kutatóintézetbe, ahol Tóth Péter rendelkezésére bocsátottuk.

Összesen 5 mázas csempeminta elemzése történt meg. Ebből kettő, a 3. és az 5. számú volt fekete mázú. (Az 1., 2. és 4. számú kályhacsempék vizsgálata más okból történt.)

\section{A vizsgálat eredménye}

A vizsgálat során alapvetően a máz színével kapcsolatos kérdésre kerestünk választ. Ezért pontszerủen elemeztük a máz egyes, általunk tipikusnak vélt részeit. A kerámia cserepét, a mázak alsó és felső részét, és a mázban levő zárványokat. A vizsgálat részletes közlése, és a többi kályhacsempe máz vizsgálatának ismertetése túlmutatna a cikk keretein.

A technológiai hibákat kizárhattuk:

- A máz "füstössége" kizárható, mert nem láttunk fém ólom gömböket a mázakban.

- A máz nem „ette meg” az engóbot, mert nincs engób a máz alatt. A mázak teljes keresztmetszetükben feketék.

A szándékosan feketére színezett mázat nem erősítette meg a vizsgálat, mert a megszokott színezőanyagokat nem láttuk a mázban.

Három szokatlan jelenséget láttunk:

- A középkori mázakhoz képest ezekben a mintákban a megszokottnál kevesebb ólom van jelen. A mázaknál alul ólomban dús, felül valamivel kisebb ólomtartalmú rétegre vált szét a máz. Ha nagyon alacsony egy máz ólomtartalma, akkor az csakigen magas hőmérsékleten olvad meg. A kályhacsempének azonban átlagos vörös színű, porózus cserepe van, tehát semmiképp nem lehet nagyon magas hőmérsékleten égetett kerámia. ${ }^{25}$

- Ennél talán még szokatlanabb, hogy a vas mennyisége a megszokott mennyiségnek többszöröse volt. Egyes foltok pedig nagyrészt vasat tartalmaztak. A mázak egyenetlen összetétele a középkori mázaknál természetes. A mázakban levő zárványok igen fontosak, mert a mázak egyes alkotórészeire lehet következtetni belőlük.

- Színezőanyagok. A vizsgálatnál jelen voltam, és a mázat feketére színező anyagokra számítottam: kobaltra, mangánra, rézre. El kellett fogadnom, hogy ezek az anyagok nincsenek jelen a mázban. Ez az eredmény kizárja a reneszánsztól ismert, és máig használt fekete mázat.

25 A kályhacsempéknél elönytelen a magas hömérsékletű égetés, mert a tömörre égetett anyagú csempék nem tartják olyan jól a hőt, mint a porózus kerámiák. 

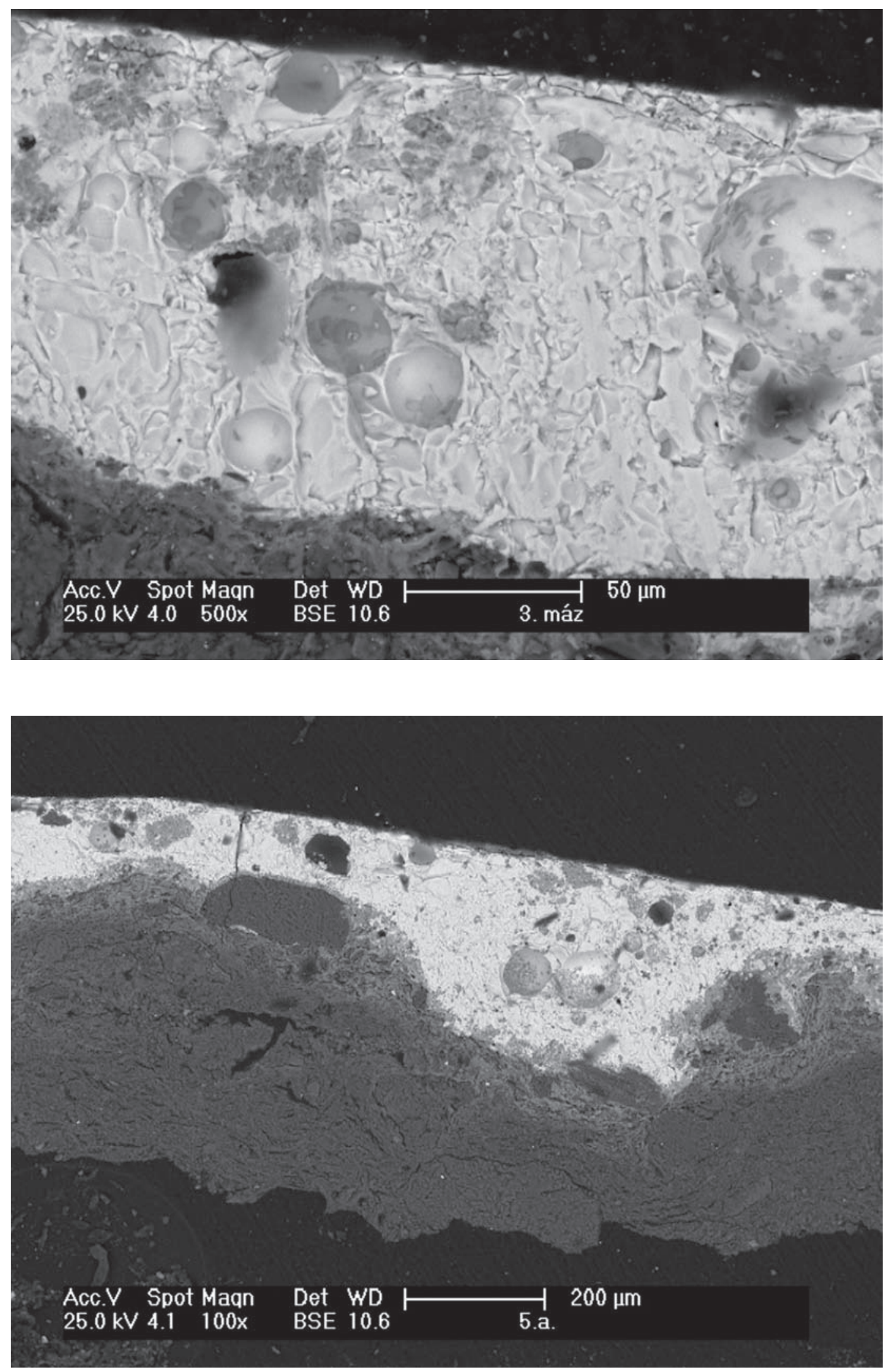

3-4. kép: 3. és 5. minta elektronmikroszkópos képe 
Label A: 3. máz 25keV

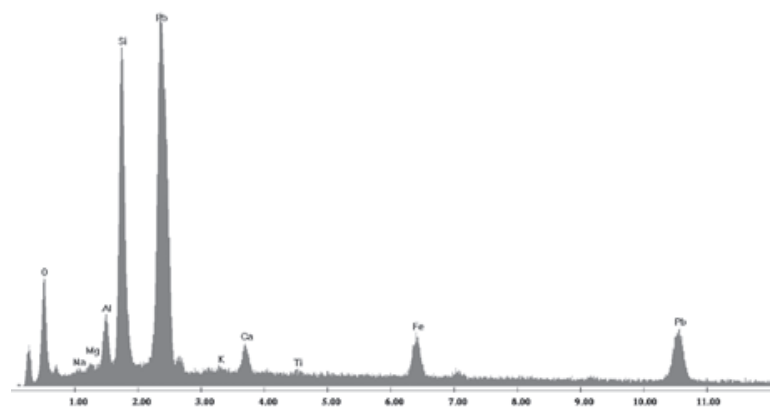

Label A: 3. máz sötét folt $25 \mathrm{keV}$

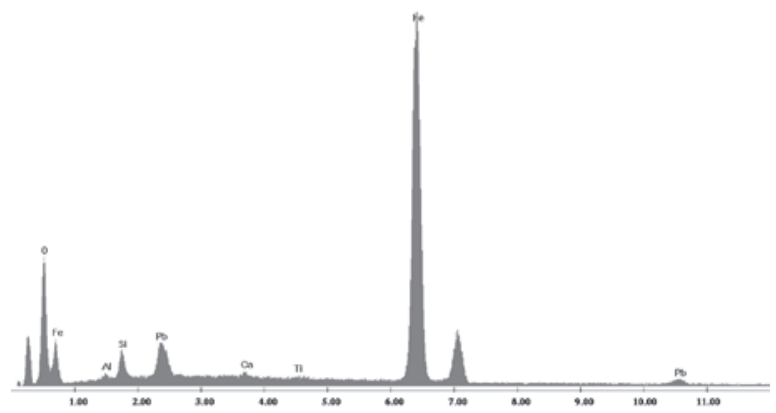

Label A: 3. máz felső töredezett rész $25 \mathrm{keV}$

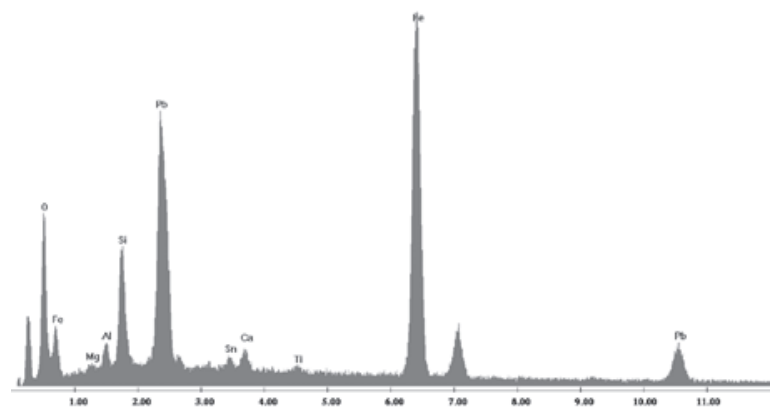

Label A: 5. átmenet alsó $25 \mathrm{keV}$

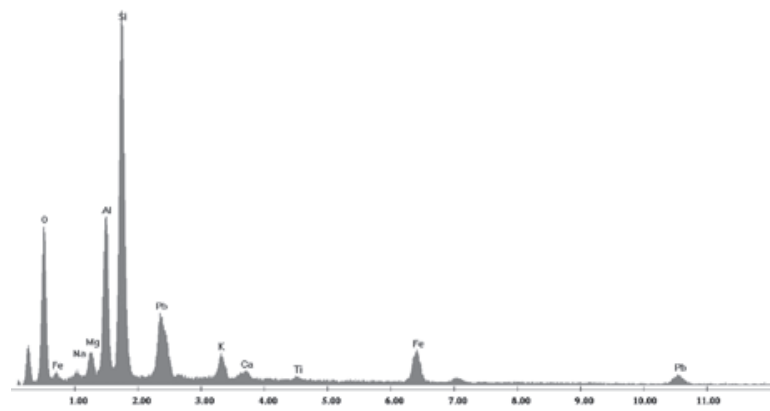

Label A: 5. máz sötét folt 1. 25keV

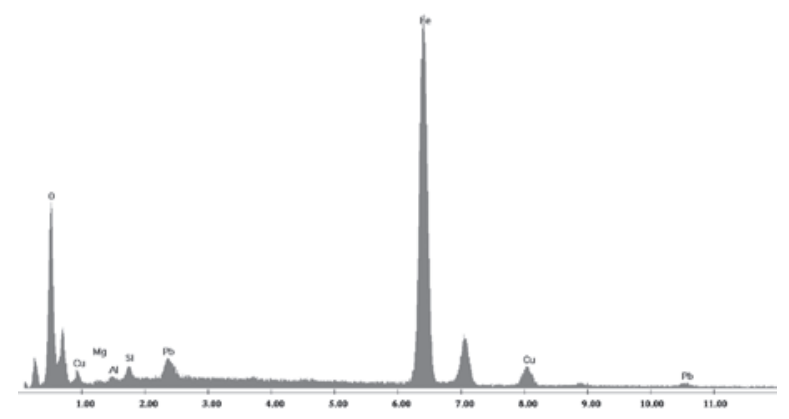

5-9. kép. A mázakat alkotó anyagok

A színezőanyagok közül az egyik mintában csak a vas van jelen, ami alapján ennek okkerszínú máznak kéne lennie. Azonban a vas mennyisége döbbenetesen nagy (a szokásos mennyiség sokszorosa). A vas túladagolása esetén egy barna, nem üvegszerú és nem fényes mázat kapunk. (Ennek a színezőanyagnak a túladagolása nem okoz grafitos színt.) Redukciós égetés esetén inkább piszkoszöld szín jellemző.

A másik mintában a vassal együtt jelen levő réz nem hoz létre fekete színt (sárgászöld lenne).

A mázban igen egyenetlen az összetevők eloszlása, ami egy középkori mázban természetes. A mázon néhány ponton végeztünk csak méréseket. Nem készült elemtérkép, sem más komolyabb vizsgálat, mert a kérdés csak annyi volt, hogy a fekete színú máz tudatos, vagy pedig egy technológiai hiba (véletlen) eredménye. Azonban a csempék vizsgálatának eredményének tudatában később érdemes lesz egy részletesebb vizsgálatot végezni.

Így már nem csak a szín tudatossága volt kérdés, hanem az is, hogy ez a máz egyáltalán hogyan olvadt meg a kerámián? A fekete szín eredetére sem kaptunk magyarázatot a vizsgálattól.

Az biztos, hogy a mázban levő vas egy fekete színú vas-oxidból ered. A vizsgálat során bizonyossá vált, hogy a fekete színt fekete vas-oxid okozza. Ez azonban nem az égetés közben keletkezett redukciós atmoszféra hatására történt. A zárványok alapján valószínúbbnek tűnik, hogy az alapanyag valamilyen módon már "készen” tartalmazott fekete vas-oxidot. 


\section{Hogy olvadhat meg az ilyen kis ólomtartalmú máz?}

Az ólmon kívül egy máz tartalmazhat más olvasztóanyagokat. ${ }^{26} \mathrm{~A}$ reneszánsz idején az ólom egy részét égetett borkővel helyettesítették. ${ }^{27}$ Ez kimutatható lenne, mert magas kálium tartalma lenne a máznak. Elvileg lehet bór tartalmú máz, amit a mikroszonda nem képes kimutatni, mert a vizsgálat szempontjából a bór „túl könnyü". Ennek kimutatására más vizsgálatot kell végezni. A középkori mázakban nem valószínú jelentős mennyiségủ bór előfordulása.

\section{A középkori mázak felépítése}

Egy középkori máz ólom-oxid és őrölt (vagy őrlés nélkül használt) homok keveréke, amihez színezőanyagot (anyagokat) is hozzákevernek. A viszonylag durva szemcsék miatt a mázak összetétele nem homogén. Ha rekonstruálni szeretnénk a megvizsgált csempe fekete mázát, rengeteg azonos mennyiségú vas-oxidot és homokot kéne összekeverni kevés ólom-oxiddal, akkor az a kemencében nem olvadna meg és nem lenne fekete. ${ }^{28}$ Fazekas szemmel nézve bizonyos, hogy egészen más módon jutunk csak megoldáshoz. Ennek rekonstruálására a fazekasokétól egészen eltérő gondolkodásra van szükség.

\section{Fayalit és a wüstit}

Az anyagvizsgálatok után, 2011 nyarán látogattam meg Somogyfajszon kísérleti régészeti táborában Thiele Ádámot. Az Árpád-kortól a Rákóczi szabadságharcig használt ősi kohó rekonstrukciójával vasbucát állított elő a csapatával. A vas előállításának mellékterméke egy szürke vagy fekete színű salak, ami összetétele szerint vagy vas-szilikát (fayalit) vagy vas-oxid (wüstit).

A tiszta fayalit $2 \mathrm{FeO} . \mathrm{SiO}_{2}$ másképp: $\mathrm{Fe}_{2}\left(\mathrm{SiO}_{4}\right)$ összetételú kőzetalkotó szilikát ásvány. Relatív molekulatömege 203,79. Nezoszilikát, rombos szerkezete van. Sürűsége 4,3, keménysége 6,5-7.1205 ㄷ-on olvad. ${ }^{29}$

Wüstit közelítőleg FeO. Relatív molekulatömege 71,85. Kősó típusú rácsa van. Sürűsége 5,9, keménységre nem találtam adatot, $1369{ }^{\circ} \mathrm{C}$-on olvad..$^{30} \mathrm{~A}$ vas rácspontjainak közel $5 \%$-a nincs betöltve (kis vashiánnyal kell számolni).31

A Thiele Ádámtól kapott anyag egyike sem tiszta fayalit vagy tiszta wüstit, ami nagyon szerencsés a kísérletek szempontjából, hiszen a középkorban hasonló módon elóállított, szennyezett alapanyagokat használtak. Úgy gondoltam, hogy ezt a két anyagot érdemes lehet megvizsgálni, hogy alkalmas-e fekete máz készítésére. Mindkét anyag nem sokkal 1000 fok felett olvad, tehát reálisnak látszik, hogy több-vagy kevesebb ólom-oxid hozzáadásával már valamivel 1000 fok alatt olvadó máz készíthető belőle.

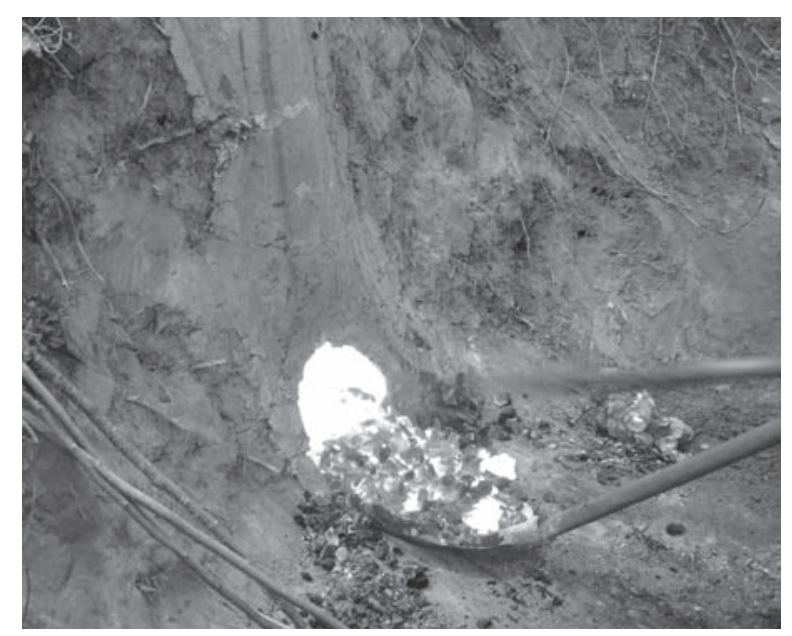

10. kép: Salak kiszedése a kohóból

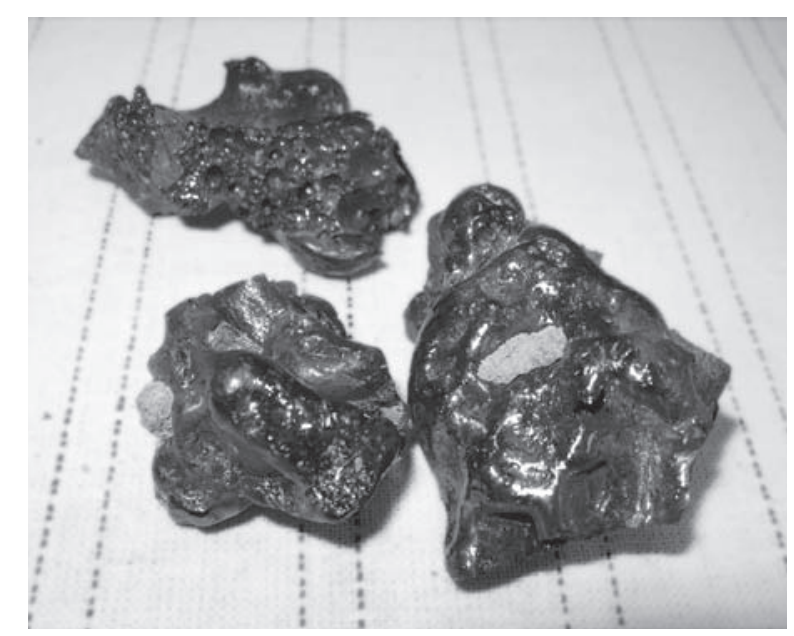

11. kép: Fayalit tartalmú salak

$261000^{\circ} \mathrm{C}$ alatt a következők: alkáliák: kálium, nátrium, ma esetleg lítium, a bór, és a 20. század elején a bárium.

27 Kálium-karbonát.

28 Mázreceptekkel foglalkozni csak annak érdemes, aki jártas a mázkészítés gyakorlatában is. A legismertebb negatív példa a Wartha Vince által közölt, Szerencsi Mihály fazekas ,,habán” mázreceptjei, amelyek összetevői valósak, de az arányok nem.

29 Tamás 1982. 135. és 165. A 6,5-es keménységi adat: Römpp 1960.a. 624. Illetve a fayalitot tárgyalja a Magyar Nagylexikon 7. kötet 716 .

30 Tamás 1982. 163. és 168.

31 Römpp 1960.b. 808. 


\section{Máz készítés}

Mindkét fajta salakot porrá törtem. Az őrlés során folyamatosan kisebb-nagyobb vas szemcsék bukkannak elő a salakokból, amelyek a további őrlést nehezítették. Ezeknek a vas-szemcséknek nagy része mágnessel eltávolítható a salakporból. Cseréplapokra festettem próbát először a tiszta, majd az egyre több ólom-oxiddal kevert őrölt salakkal.

Az égetés eredménye: a wüstit (vas-oxid) csak sok ólom-oxidtól olvadt meg, és nem volt olyan folyós máz. (A nyírbátori csempék máza folyós.)

A fayalit igen kevés ólom-oxidtól is megolvadt, és folyós, fekete mázat alkotott. Ehhez 9 rész fayalithoz adott 1 rész ólom-oxid elegendő. A máz folyós, és a madár címeres (1. sz.) csempékhez hasonlóan bizonyos szögből nézve fémesen csillog.

A nyírbátori csempék fekete mázát készítő mester valószínűleg találkozott a vas előállítás melléktermékként keletkező salakkal. Talán csak a salak fekete színe (és az a tény, hogy magas hőmérsékleten keletkezett, tehát kerámia szempontjából stabil) adhatta az ötletet, hogy kipróbálja fekete máz készítéshez.

Ha egy átlagos, mázak készítésében járatos fazekas próbálta volna ki, valószínűleg akkor színezőanyagként próbálta volna mázba keverni. Ekkor valószínűleg hagyományos okkersárga mázat kapott volna. Ezzel szemben magát a salakot akarta megolvasztani annyira, hogy mázként használható legyen. Ez a gondolkodás fazekasnál szokatlan, de a végeredmény szempontjából eredményes volt. A fayalit szerencsés módon remekül használható fekete máz készítésére.

Igazán sajnálhatjuk, hogy nem terjedt el ez a fekete máz készítési módszer. Sokkal olcsóbb így fekete mázat készíteni (nem kell bele az igen drága kobalt), és egészségesebb is, hiszen igen alacsony az ólomtartalma. Nagyon valószínü, hogy a csekély mennyiségű ólom már nem oldódik ki a mázból gyengén savas italok és ételek hatására. Ráadásul „környezetbarát”, mert hulladékot hasznosít újra. Hogy miért nem terjedt el ez a máz, azt nehéz megmondani. Talán a kohók salakjának minősége (összetétele) változékony. Így az egyik salak alkalmas volt fekete máz készítésére, a másik pedig nem. Talán emiatt bizonytalan volt a fekete máz készítése. Az biztos, hogy a vasgyártás fejlődésével a salak egyre kevesebb vasat tartalmazott, így idővel a felhasználható salak mennyisége is csökkent. Reméljük, hogy később közelebb jutunk a megoldáshoz.
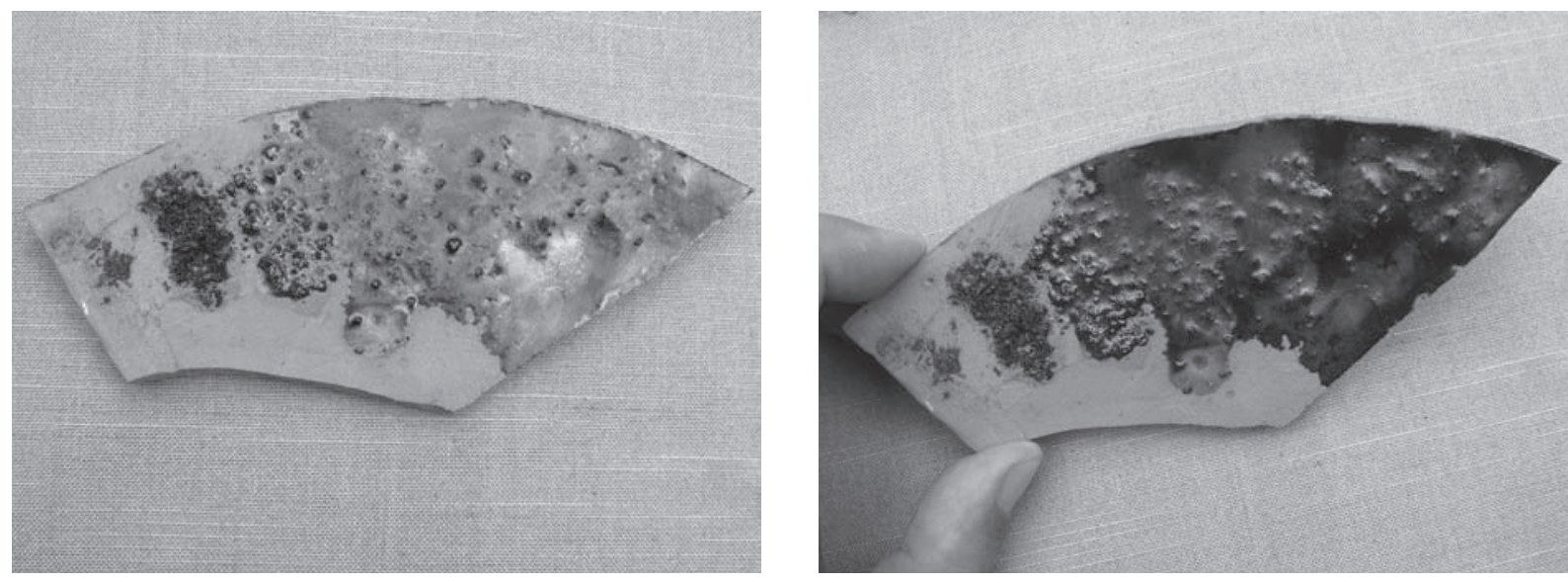

12-13. kép: Fayalitos máz. Fémes csillogás látható a mázon bizonyos szögböl nézve

\section{A nyírbátori csempék fekete mázának besorolása}

Az eddig megismert máztípusokat leggyakrabban az összetétel alapján ólmos és ólommentes mázak nagy csoportjára osztják. Az ólmos mázak kémiai szempontból ólom-szilikátnak tekinthetőek. (Az ólom-szilikátokból nagyon sok féle van.) Az ólommentes mázak alkáli-szilikát vagy bór-szilikát alapúak (esetleg ezek keverékei). Az alkáli-szilikátok inkább 1000 fok feletti hőmérsékleten olvadó mázak, a bór-szilikát alapúak az előbbinél valamivel alacsonyabb hőmérsékletre készülnek. A nyírbátori kályhacsempék fekete máza vasszilikát alapú, ami leginkább az ólommentes mázakhoz sorolható lenne, de a kis ólomtartalom miatt inkább a kettő közé. Több egyedi tulajdonságai miatt, és a szokatlan kiinduló anyag (fayalit anyagú salak) miatt érdemes egy harmadik máz kategóriának tekinteni. Valójában az első két mázcsoporttól eltérő tulajdonságú máztípust ismerhettünk meg. 


\section{Összefoglalás}

A nyírbátori két fekete mázú kályhacsempe szemrevételezése során nem lehetett eldönteni, hogy a fekete szín technológiai hiba következménye, vagy tudatos színezés eredménye. Az elektronmikroszkópos vizsgálat során kapott összetétel eredménye alapján eltér a mai mázaktól, és a középkori kályhacsempe mázaktól egyaránt. Egy egészen egyedi összetételú mázat találtunk. Az ilyen alacsony ólomtartalmú, és nagy vastartalmú máz elvileg egy középkori fazekaskemencében meg sem olvadhat. Ennél szokatlanabb, hogy a fekete mázban a színezőanyagok közül egyedül vasat találtunk. Ennek jelenléte önmagában nem magyarázza a máz fekete színét. Ezek a jelenségek együtt nem magyarázhatóak meg hagyományos fazekasmázak ismeretében, és nem állíthatóak elő hagyományos fazekasok által megszokott módszerekkel. Mindezek megoldásához a fazekasok gondolkodásától eltérő gondolkodásra, és egy egészen szokatlan alapanyagra volt szükség. Ez az anyag a korabeli vas előállítás során melléktermékként keletkező salak, amely ásványi nevén fayalit, kémiai szempontból pedig vas-szilikát. Továbbá az is fontos, hogy a fekete színű vas-szilikát anyagú salakot a megszokottól eltérő módon nem színezőanyagként, hanem mázalkotóként használta a mester (mintha egy mázfritt lenne). Az égetési kísérletek segítségével megkíséreltem rekonstruálni ezt a szokatlan módon készült mázat. Ennek során úgy találtam, hogy fayalittal valóban készíthető máz, amely a kályhacsempéken látható egyéb szokatlan jelenségeket (pl. fémes csillogás bizonyos szögből) is mutatta. További érdekesség, hogy a kályhacsempéken levő vas-szilikát összetételű, kevés ólom-oxidot tartalmazó máz nem sorolható be könnyen a hagyományos mázak két nagy csoportjának egyikébe sem.

\section{Überraschendes Untersuchungsergebnis der schwarzen Glasur der 2 mittelalterlichen Ofenkacheln und dessen Erklärung}

\section{PÉTER VÉNINGER}

Während der Untersuchung der 2 schwarz glasierten Ofenkacheln, konnte nicht festgestellt werden, ob die schwarze Farbe Wirkung eines technischen Fehlers oder Ergebnis einer bewussten Färbung war. Aufgrund des Ergebnisses der mit einem Übermikroskop gemachten Prüfung, unterscheidet sich die Farbe nicht nur von den heutigen Glasuren sondern auch von den mittelalterlichen Ofenkachelglasuren. Wirfanden eine ganzeinzelnezusammengesetzteGlasur. Eine solche Glasur mit niedrigem Bleigehalt und hohem Eisengehalt kann grundsätzlich in einem mittelalterlichen Töpferofen nicht geschmolzen werden. Es ist zudem ungewöhnlich, dass wir in der schwarzen Glasur nur das Eisen von den Farbstoffen fanden. Seine Existenz selbst erklärt die schwarze Farbe der Glasur nicht. Diese Erscheinungen zusammen können mit den Kenntnissen der traditionellen Töpferglasur nicht auseinandergesetzt werden und können durch die gewöhnlichen Methoden der traditionellen Töpfer nicht nachgestellt werden. Zu dieser Lösung wurde eine ganz andere Denkart als die des traditionellen Töpfers und einen ganz besonderen Grundstoff gebraucht. Dieser Stoff ist die, während der zeitgenössischen Eisenherstellung, als Abfallprodukt entstehende Schlacke, deren mineralischer Name Fayalit und der chemische Name Eisen-Silikat ist. Zudem ist wichtig, dass der Töpfer die schwarze Schlacke aus Eisen-Silikat ungewöhnlicherweise nicht als Farbstoff, sondern als Glasurstoff benutzte, als ob sie ein Glasurfrit wäre. Mit Hilfe der Brandexperimente versuchte ich diese ungewöhnliche hergestellte Glasur zu rekonstruieren, derzufolge ich herausfand, dass mit Fayalit wirklich Glasuren herzustellen sind, die auch auf den Ofenkacheln sichtbare Erscheinungen (wie z. B. metallischen Glanz aus bestimmten Winkeln) zeigen. Eine weitere Besonderheit ist, dass die aus Eisen-Silikat zusammengesetzte und wenig Bleioxid enthaltende Glasur der Ofenkacheln nicht einfach in den beiden großen Gruppen der gewöhnlichen Glasuren eingeordnet werden kann.

\section{Irodalom}

Duma Gy. 1977.: Kályhacsempék mázai a XV. században. Múzeumi Mütárgyvédelem 1977/4. 133-145.

Gebauer W. 1985.: Kézműipari kerámia. Budapest

Hinsenkamp A. - Falussy G. - Richter V. 1961.: Kerámiai művezetők zsebkönyve. Budapest

Jakó G. 1934.: Az agyagáruk ismertetése és gyártása, különös tekintettel az építészeti kerámiára. Debrecen

Kozma B. 1998.: A kerámiamázak. Szeged

Mattyasovszky-Zsolnay L. 1953.: Finomkerámiai kézikönyv I. Budapest

Papp J. 1906.: Az agyagipar technológiája. Iparosok Olvasótára 12/1-2.

Papp J. 1907.: A különböző agyagárúk gyártása. Iparosok Olvasótára 13/1-2.

Petrik L. 1914.: Az agyagiparos. Budapest

Römpp H. 1960.a.: Vegyészeti lexikon I. Budapest

Römpp H. 1960.b.: Vegyészeti lexikon III. Budapest

Somodi Zs. - Pálffy A. - dr. Kámory L. 1984.: Finomkerámiaipari technológia. Budapest

Tamás F. 1982.(Szerk.): Szilikátipari kézikönyv. Budapest 